\title{
Acquisition Fund: An unrecognised treasure within the cultural policy of the Czech Republic
}

\author{
Lucia Horňáková - Marek Prokůpek
}

Lucia Horňáková

$\mathrm{PhD}$ candidate

Prague University of Economics and Business

Department of Arts Management

Czech Republic

e-mail: lucia.hornakova@vse.cz

ORCID: 0000-0003-3734-7756

Marek Prokůpek, $\mathrm{PhD}$

Prague University of Economics and Business

Department of Arts Management

Czech Republic

e-mail: marek.prokupek@vse.cz

ORCID: 0000-0003-4564-8962

Muzeológia a kultúrne dedičstvo, 2021, 9:2:45-59

DOI: $10.46284 / \mathrm{mkd} .2021 .9 .2 .3$

Acquisition Fund: An unrecognised treasure within the cultural policy of the Czech Republic

The paper elaborates on the Acquisition Fund for Contemporary Art established in 2017 in the Czech Republic by the Ministry of Culture. Paradoxically, this fund is perceived both positively and negatively by various institutions. On the positive side, from the year 2017 to 2019, the fund has allocated 41,257,888 CZK (1,517,753 EUR) for the purchase of 287 artworks by 29 institutions. On the negative side, only 29 out of 218 eligible institutions have applied for support from the fund during the three years of the fund's existence. This low application rate is attributed partly to the time consuming and complicated administration of the application for support, and partly to apprehension from some institutions regarding the likelihood of the actual realisation of the receipt of financial support. In turn, due to this low application rate, the institutions that have applied have had a high probability of receiving funding. The paper sheds new light on the lack of financing for acquisition in art institutions and opens the question of the effectiveness of the Acquisition Fund in the Czech Republic.

Keywords: acquisitions, contemporary art, acquisition fund, art museum, art collecting

\section{Introduction}

Acquisition, as one of the critical features of museums, should never be neglected. Unfortunately, due to increasing operational costs and decreasing public subsidies, public Czech art museums have struggled, with the lack of financial sources, to extend their collections. Consequently, many public art museums in the Czech Republic have not achieved their collection missions. Therefore, there is a risk that contemporary artistic creations will be absent in the collections of Czech public art museums.

Moreover, although the Czech Republic is primarily considered a culturally developed country, its contemporary art scene's weakness is significant. This weakness is most prominently manifested in the lack of a national contemporary art institution. This void in contemporary art is currently compensated in three ways. First, the National Gallery Prague collects and presents artworks and masterpieces from Medieval Art to contemporary art. Second, the regional art museums network aims to collect and exhibit contemporary art, even though it 
is not their primary focus, and even with minimal resources. Third, compensation also occurs by the eclectic collections of private art museums, art centres and commercial art galleries financed majorly by their founders. Private art museums have become important players in the landscape of contemporary art in the Czech Republic in the last few years. The sector has recently witnessed a rise of such institutions, usually created by businessmen who possess modern and contemporary art collections.

While the Czech Republic lacks the finance and policymakers' effort to create a national contemporary art institution, the Ministry of Culture is aware of this cultural gap. It has, therefore, included partial solutions in the State Cultural Policy for 2015-2020. Beyond this central cultural policy conception, the Ministry of Culture of the Czech Republic has developed a document focused solely on museums called The Concept Of Museum Development In The Czech Republic for The Years 2015 to 2020, and it is the first of its kind in the Czech Republic. As a part of such policies, the Ministry of Culture planned to establish the Acquisition Fund for contemporary art in 2017. This paper reacts to the creation of this fund and aims to explore and evaluate the fund's role in contemporary art acquisitions.

\section{Methodology}

The research employs grounded theory, ${ }^{1}$ and more precisely, a constructivist grounded theory, ${ }^{2}$ which assumes that the researchers construct theories due to their interactions with the field and its participants.

By coding, thematising, and generalising semi-structured interviews, authors define the main issues related to the application process for the relatively newly launched Acquisition Fund in the Czech Republic. These semi-structured interviews were conducted with ten directors of the regional art museums in the Czech Republic listed in Table 1 in alphabetical order. The interviews were conducted in the period from July to September 2019. Each interview lasted from 40 to 60 minutes and was recorded and transcribed. The final interview, with a representative of the Ministry of Culture of the Czech Republic, the ministry responsible for the Acquisition Fund agenda, was held in written form via email in May 2020.

Moreover, authors used data from interviews with representatives of three commercial art galleries focusing on contemporary art that were conducted in August and September 2018, specifically with the representatives of the Polansky Gallery, the Nevan Contempo, and the DSC Gallery.

Additionally, the Acquisition Fund's effectiveness over the three years is assessed through the examination of statistical data obtained from the Ministry of Culture of the Czech Republic.

Tab. 1.

\begin{tabular}{|l|l|l|}
\hline $\begin{array}{l}\text { Original name of the art mu- } \\
\text { seum }\end{array}$ & $\begin{array}{l}\text { English translation of the art } \\
\text { museum name }\end{array}$ & Website \\
\hline Alšova jihočeská galerie & Aleš South Bohemian Gallery & www.ajg.cz \\
\hline Galerie Klatovy / Klenová & Klenova District Gallery & www.gkk.cz \\
\hline $\begin{array}{l}\text { Galerie moderního umění v } \\
\text { Hradci Králové }\end{array}$ & $\begin{array}{l}\text { Gallery of Modern Art in Hra- } \\
\text { dec Kralove }\end{array}$ & www.galeriehk.cz \\
\hline
\end{tabular}

\footnotetext{
${ }^{1}$ GLASER, Barney G. and STRAUSS, Anselm L. The discovery of grounded theory: Strategies for qualitative research. London: AldineTransaction, 1967.

${ }^{2}$ CHARMAZ, Kathy. Constructing grounded theory. London: SAGE Publications, 2014.
} 


\begin{tabular}{|l|l|l|}
\hline $\begin{array}{l}\text { Galerie moderního umění v } \\
\text { Roudnici nad Labem }\end{array}$ & $\begin{array}{l}\text { Gallery of Modern Art Roudni- } \\
\text { ce nad Labem }\end{array}$ & www.galerieroudnice.cz \\
\hline $\begin{array}{l}\text { Galerie výtvarného umění v } \\
\text { Chebu }\end{array}$ & The Art Gallery in Cheb & www.gavu.cz \\
\hline $\begin{array}{l}\text { Galerie výtvarného umění v } \\
\text { Havlíčkově Brodě }\end{array}$ & $\begin{array}{l}\text { The Art Gallery in Havlickuv } \\
\text { Brod }\end{array}$ & www.galeriehb.cz \\
\hline $\begin{array}{l}\text { Galerie výtvarného umění v Ná- } \\
\text { chodě }\end{array}$ & The Art Gallery in Nachod & www.gvun.cz \\
\hline $\begin{array}{l}\text { GASK - Galerie Středočeského } \\
\text { kraje }\end{array}$ & $\begin{array}{l}\text { GASK - the Gallery of the Cen- } \\
\text { tral Bohemian Region }\end{array}$ & www.gask.cz \\
\hline Oblastní galerie Liberec & Regional Gallery of Liberec & www.ogl.cz \\
\hline $\begin{array}{l}\text { Východočeská galerie v Pardu- } \\
\text { bicích }\end{array}$ & $\begin{array}{l}\text { East Bohemian Gallery in Par- } \\
\text { dubice }\end{array}$ & www.vcg.cz \\
\hline
\end{tabular}

\section{The Art Museum Sector in the Czech Republic}

The development of the museum sector in Czech lands started at the end of the eighteenth century and the beginning of the nineteenth century. In the last thirty years, the sector has undergone significant changes. ${ }^{3}$ Since 1990 the public sector has been undergoing a reform related to the change in the state's territorial organisation and the launch of new entities providing public services. There were seven administrative regions until 1999. Today, there are fourteen administrative regions. As a part of the public administrational reform, a hypothesis that each region would have at least one historical and one art museum was adopted. ${ }^{4}$

In 2002 the second wave of the reform was completed and included the extinction of seventy-six district offices, and some of their competencies were transferred to regional administrations. During the first wave of the reform, eight general museum and nineteen art museums were transferred from the Ministry of Culture's governance to that of administrative regions. During the second wave, sixty-three general museums and one art museum went through the same governmental transformation. ${ }^{5}$

Regions operate on the basis of Act No. 129/2000 Coll. on Regions (Establishment of Regions), as amended. Regional administrations make independent decisions, take care of their territory, development, citizen satisfaction and support of culture and its development, and help fulfil the government's concepts following its recommendations. Saying this, it is the regional administration which is the founder of regional art museums. It sets up an institution by issuing a founding document which lists its name, registered office, identification number, legal form, main purpose of the institution, subject of activity, statutory body, definition of property and property rights, additional activities, and economic standards. The regional art museum, as a non-profit organisation, performs the given tasks to satisfy the public interest and is a legal entity under public law. Budget-wise, it follows Act No. 250/2000 Coll. on Municipal Budgetary Rules, which regulates expenses and support from regional and municipal budgets. The regional art museums are financed majorly from the public budget, that is, following Decree No. 397/2017 Coll., structured into 4 sub-funds:

\footnotetext{
${ }^{3}$ PROKŮPEK, Marek. Ekonomika a měreni výkonnosti mužé. Praha: Wolters Kluwer ČR, 2020, p. 20.

${ }^{4}$ FIALOVÁ, Dagmar. Profesni a etické standardy a výkonnostni ukazatele muzejní práce. Praha: Asociace muzeí a galerií, 2003, p. 32

${ }^{5}$ FIALOVÁ, Dagmar. Profesní a etické standardy..., p. 32
} 
- Investment Fund,

- Remuneration Fund,

- Reserve Fund,

- Cultural and Social Needs Fund.

The budget is set up by the organisation itself and the founder approves it. The regional administrations "compete" for the funds with national level administrations and municipalities. Regional budgets are provided with approximately $27.2 \%$ of the overall state expenditures on culture, out of which the cultural heritage sector on the regional level, including historical and art museums, gets approx. $35.7 \%$ (1.21 billion CZK or 559.2 million EUR). ${ }^{6}$

According to The National Information and Consulting Centre for Culture, in 2018, there were 477 museums in the Czech Republic, while in 1999, the number of museums was 436. In 2018, there were 45 art museums, 39 of them being organisations funded by the Ministry of Culture or other ministries, regions or municipalities. Entrepreneurial units fund two art museums, and four are listed as run by associations, churches or other non-governmental, nonprofit organisations. ${ }^{7}$

Of course, museums must comply with legislation. The most important one for museums is Act No. 122/2000 Coll. on protecting collections of a museum character and applying specific laws. This act replaced the previous one from 1959 and defined a museum, its collection and its purpose. It says that a museum is an institution that acquires and collects natural and human creations.

Therefore, building a collection is at the core of museums' activities. Museums have historically faced issues regarding acquisition budgets. In the past, the budgets of Czech art museums did not include a specific part dedicated to acquisitions. Acquisitions were made only if a museum had succeeded in saving money. The critical change was brought about by the force of Decree No. 397/2017 Coll. Since January 1st, 2018, art museums are obliged to buy artworks from sources allocated in the Investment Fund of the art museums' budget structures. As Act No. 122/2000 Coll. declares, museum activities are partly or wholly financed from public budgets. Thus, each regional administration directly assigns sources incorporated into art acquisition investment funds following the new decree. The change has partly affected even the existing ministerial programme named ISO C, which offers financial support of up to $100 \%$ of costs for acquisitions of objects with a cultural value of particular significance. Now, the programme allocates support as both investment and non-investment funds.

\section{Acquisitions of Contemporary Art}

The collecting and preserving of objects have traditionally been a central function of museums. The collection gives the museum its character and determines its purpose. ${ }^{8}$ Collecting is, therefore, the raison d'être of museums. The museum's approach to collecting focuses on a certain phenomenon of reality, which has a transparent cognitive and value meaning. Museums select from reality such objects that have been an authentic part, and thus also witnesses of its

\footnotetext{
${ }^{6}$ PETROVÁ, Pavla. Compendium - Country profile - Cžech republic. 2020. Accessed May 16th, https://www.culturalpolicies.net/database/search-by-country/country-profile/category/?id=9\&g1 $=1$

${ }^{7}$ NÁRODNÍ INFORMAČNÍ A PORADENSKÉ STŘEDISKO PRO KULTURU. Základní statistické údaje o kultuře v České republice 2018. Praha: NIPOS, 2019, pp. 9-15

${ }^{8}$ GENOWAYS, Hugh H. and IRELAND, Lynne M. Museum administration: An introduction. Altamira Press, 2003.
} 
existence. ${ }^{9}$ As Ryan points out, ${ }^{10}$ the acquisition is a unique moment in time for contemporary artworks as the various stakeholders are interested in defining the artwork and its conditions for purchase, resulting in discussion and evaluation from a wide variety of perspectives.

In last four decades, the focus has shifted from pure collection stewardship toward a more visitor-oriented approach. ${ }^{11}$ Museum exhibitions play a crucial role in establishing the value of contemporary art. While speaking about the value of an artwork, we distinguish two types of value, formulated by Karl Marx: value and exchange value. ${ }^{12}$ Museum exhibitions impact the art market ${ }^{13}$ since they are considered to be arbiters of the quality of works. ${ }^{14}$

The collecting of contemporary art by museums is an essential aspect in documenting our society and its development and raises several issues ranging from challenges to the traditional conception of the art museum to changing the character of contemporary art. ${ }^{15}$ One of the issues may be the fact that after some time, art which was once considered as contemporary becomes historical, and is included in the history of art and thus loses the status of the present. The second issue with the creation of a collection of contemporary art can be caused by the instability of forms of contemporary art and also of the materials that contemporary artists use to create their works. Often the works are only temporary in nature or are made of materials that are very difficult to store for a long time. Much of contemporary art is essentially intangible in nature, or is recorded in the form of electronic data. The musealisation of these objects can be an interesting challenge for art museums.

\section{The Acquisition Fund for Contemporary Art}

A key point in the Czech Republic's current cultural policy is the Acquisition Fund of the Ministry of Culture. This fund was set up in 2017 to compensate for the underfunded museums' budgets and art museums established not only by the regional administrations but also by private institutes.

The Acquisition Fund's objective is to ensure that contemporary art phenomena, which represent fine arts development in the Czech Republic, are perceived in an international context and are collected, preserved and accessible to the public. Additionally, a conceptual and coordinated approach to contemporary art representation can enliven a commercial art market. Art museums must acquire artworks of emerging artists in their initial career before the prices of their art increase. On the other hand, acquisitions from a young art scene help position living artists on the market. The Acquisition Fund serves the visual art field, and specifically, art museums solely. The acquisitions that can be submitted to the selection process need to be: works of fine art, or an original author's documentation of fine art, including

\footnotetext{
${ }^{9}$ STRÁNSKÁ, E. and STRÁNSKÝ, Z. Ozvláštnění skutečnosti: sběratelství a sbírkotvorná činnost. In: Pachmanová, M. (ed). Mit a být, sbèratelství jako kumulace, recyklace a obsese. Praha: Vysoká škola uměleckoprůmyslová, 2008. ISBN 978-80-86863-25-2, s. 43-44

${ }^{10}$ RYAN, Gwynne. Considerations in the acquisition of contemporary art: Refabrication as a preservation strategy. In: Studies in Conservation, 2016, pp. 198-202.

${ }^{11}$ ALTSHULER, Bruce (ed.). Collecting the new: museums and contemporary art. Princeton University Press, 2007.

${ }^{12}$ NAIRNE, Sandy. Exhibitions of contemporary art. In: Barker, E. (ed). Contemporary Cultures of Display, 1999 , pp. 105-126.

${ }^{13}$ VELTHUIS, Olav. Talking prices: Symbolic meanings of prices on the market for contemporary art. Princeton University Press, 2007.

${ }^{14}$ FALK, John H. and SHEPPARD, Beverly K. Thriving in the knowledge age: New business models for museums and other cultural institutions. Altamira Press, 2006.

${ }^{15}$ ALTSHULER, Bruce (ed.). Collecting the new...
} 
original documentation of installations and an author's performance records; applied art; architectural design documentation; industrial design or its original documentation; the original of an author's photograph (or gelatin silver prints) with the original negative; video art; or an author's book. Financial support from the Acquisition Fund can be provided only to purchase artworks that have been created up to a maximum of 50 years ago.

The Acquisition Fund redistributes financial support based on the subsidy once a year through an open call. Applying institutions cannot be founded by the Ministry of Culture, since in their case, the contribution for acquisition is included in their annual subsidy. There are no limitations for privately run institutions, but the collection to be extended and funded by the fund must be registered in the Central Registry of Collections (CES). The CES was launched in 2000 as the implementation tool for Act No. 122/2000 Coll., on the protection of collections of a museum character and amendment to specific laws. It is a publicly accessible list of officially approved collections by the Ministry of Culture of the Czech Republic which are protected by law and can be financed by public funds.

\section{Ambitions vs Reality}

The Czech Cultural Policy for 2015-2020 outlines specific details regarding the foundation of the Acquisition Fund. It allocates annual financial support of 80,000,000 CZK (2,941,261 EUR) for new acquisitions of contemporary art. However, this amount has not been allocated in reality. In the first year, the Acquisition Fund distributed 10,088,810 CZK (370,941 EUR). In the second and the third years respectively, 15,453,818 CZK and 15,715,260 CZK (568,190 EUR and 577,802 EUR) were allocated. The sum of three years' funding was 41,257,888 CZK $(1,516,900$ EUR), which represents merely half of the fund's envisaged annual allocation. The representative of the Acquisition Fund has confirmed that the yearly budget can cover more applications or the purchase of more expensive artworks. ${ }^{16}$ This being said, it only proves that the Acquisition Fund is not used sufficiently.

\section{Evaluation}

Given the situation in the Czech Republic, where art institutions lack adequate finances, the fact that a new funding initiative such as the Acquisition Fund has found a less than enthusiastic response is astonishing. According to reports for the Acquisition Fund of the Ministry of Culture of the Czech Republic for the years 2017-2019, over the course of three years, just 29 different institutions (20 art museums and nine other types of museums) out of the total of 218 eligible institutions have received the awards making up the total funding of 41,257,888 CZK $\left(1,517,756\right.$ EUR). ${ }^{17}$ In the first year, 14 museums were awarded funding, and that number has been growing at a compounded annual growth rate of $11 \%$ over the three years. Only seven ${ }^{18}$ ( 6 art museums and 1 other type of museum) applied every year consecutively; the sum of their funding over three years makes $58.5 \%$, which is $24,142,474 \mathrm{CZK}(888,146 \mathrm{EUR})$ of the entire budget, and equally $58.5 \%$ (169 artworks) of the nominal quantity of artworks funded.

\footnotetext{
${ }^{16}$ Interview with Eva Teuerová, representative of the Acquisition Fund of the Ministry of Culture of the Czech Republic. Prague, April 2020.

${ }^{17}$ Centrální evidence sbírek muzejní povahy. Accessed June 19th, 2020, from http://www.cesonline.cz/arl-ces/cs/ index/

${ }^{18}$ Gallery of Moder Art in Hradec Kralove, The Art Gallery in Cheb, Jan and Meda Mládek Foundation - Museum Kampa, The North Bohemian Gallery of Fine Arts in Litoměrice, The North Bohemian Museum in Liberec, East bohemian Museum in Pardubice, Gallery of West Bohemia in Pilsen
} 
Tab. $2^{19}$

\begin{tabular}{|c|c|c|c|c|}
\hline $\begin{array}{l}\text { Institutions (ori- } \\
\text { ginal name) }\end{array}$ & \begin{tabular}{|l|} 
English \\
translation of \\
the art museums \\
name
\end{tabular} & Subsidy in 2017 & Subsidy in 2018 & Subsidy in 2019 \\
\hline $\begin{array}{l}\text { České muzeum } \\
\text { Stř́ibra v Kutné } \\
\text { Hoře } \\
\end{array}$ & $\begin{array}{l}\text { Czech Museum } \\
\text { of Silver in Kutna } \\
\text { Hora } \\
\end{array}$ & $0 \mathrm{CZK}$ & $0 \mathrm{CZK}$ & $63000 \mathrm{CZK}$ \\
\hline $\begin{array}{l}\text { Galerie hlavního } \\
\text { města Prahy }\end{array}$ & $\begin{array}{l}\text { Prague City } \\
\text { Gallery }\end{array}$ & $592900 \mathrm{CZK}$ & $420000 \mathrm{CZK}$ & $0 \mathrm{CZK}$ \\
\hline $\begin{array}{l}\text { Galerie Klatovy / } \\
\text { Klenová }\end{array}$ & $\begin{array}{l}\text { Klenova District } \\
\text { Gallery }\end{array}$ & $0 \mathrm{CZK}$ & $0 \mathrm{CZK}$ & $881000 \mathrm{CZK}$ \\
\hline $\begin{array}{l}\text { Galerie moder- } \\
\text { ního umění v } \\
\text { Hradci Králové } \\
\end{array}$ & $\begin{array}{l}\text { Gallery of } \\
\text { Modern Art in } \\
\text { Hradec Kralove } \\
\end{array}$ & $0 \mathrm{CZK}$ & $0 \mathrm{CZK}$ & $2523968 \mathrm{CZK}$ \\
\hline $\begin{array}{l}\text { Galerie moderní- } \\
\text { ho umění v Roud- } \\
\text { nici nad Labem }\end{array}$ & $\begin{array}{l}\text { Gallery of Mo- } \\
\text { dern Art Roudni- } \\
\text { ce nad Labem }\end{array}$ & $462000 \mathrm{CZK}$ & $297500 \mathrm{CZK}$ & $315000 \mathrm{CZK}$ \\
\hline $\begin{array}{l}\text { Galerie Středo- } \\
\text { českého kraje v } \\
\text { Kutné Hoře } \\
\end{array}$ & $\begin{array}{l}\text { GASK - the Gal- } \\
\text { lery of the Central } \\
\text { Bohemian Region } \\
\end{array}$ & $0 \mathrm{CZK}$ & $820800 \mathrm{CZK}$ & $1363500 \mathrm{CZK}$ \\
\hline \begin{tabular}{|l} 
Galerie umění \\
Karlovy Vary
\end{tabular} & $\begin{array}{l}\text { Karlovy Vary Art } \\
\text { Gallery } \\
\end{array}$ & $0 \mathrm{CZK}$ & $98000 \mathrm{CZK}$ & $0 \mathrm{CZK}$ \\
\hline $\begin{array}{l}\text { Galerie výtvar- } \\
\text { ného umění v } \\
\text { Chebu }\end{array}$ & $\begin{array}{l}\text { The Art Gallery } \\
\text { in Cheb }\end{array}$ & $297500 \mathrm{CZK}$ & $717500 \mathrm{CZK}$ & $706300 \mathrm{CZK}$ \\
\hline \begin{tabular}{|l|} 
Galerie výtvar- \\
ného umění v \\
Havlíčkově Brodě
\end{tabular} & $\begin{array}{l}\text { The Art Gallery } \\
\text { in Havlickuv Brod }\end{array}$ & $72450 \mathrm{CZK}$ & $0 \mathrm{CZK}$ & $0 \mathrm{CZK}$ \\
\hline $\begin{array}{l}\text { Galerie výtvar- } \\
\text { ného umění v } \\
\text { Náchodě }\end{array}$ & $\begin{array}{l}\text { The Art Gallery } \\
\text { in Nachod }\end{array}$ & $0 \mathrm{CZK}$ & $56000 \mathrm{CZK}$ & $0 \mathrm{CZK}$ \\
\hline $\begin{array}{l}\text { Galerie výtvar- } \\
\text { ného umění v } \\
\text { Ostravě } \\
\end{array}$ & $\begin{array}{l}\text { Gallery of Fine } \\
\text { Art Ostrava }\end{array}$ & $0 \mathrm{CZK}$ & $2320000 \mathrm{CZK}$ & $1942000 \mathrm{CZK}$ \\
\hline $\begin{array}{l}\text { Horácká galerie v } \\
\text { Novém Městě na } \\
\text { Moravě }\end{array}$ & $\begin{array}{l}\text { The Horácká } \\
\text { Gallery in Nové } \\
\text { Město na Moravě }\end{array}$ & $0 \mathrm{CZK}$ & $50000 \mathrm{CZK}$ & $0 \mathrm{CZK}$ \\
\hline $\begin{array}{l}\text { Krajská galerie } \\
\text { výtvarného umění } \\
\text { ve Zlíně }\end{array}$ & $\begin{array}{l}\text { Regional Gallery } \\
\text { of Fine Arts in } \\
\text { Zlín }\end{array}$ & $0 \mathrm{CZK}$ & $226800 \mathrm{CZK}$ & $657740 \mathrm{CZK}$ \\
\hline $\begin{array}{l}\text { Královská kano- } \\
\text { nie premonstrátů } \\
\text { na Strahově }\end{array}$ & $\begin{array}{l}\text { Royal Canonry of } \\
\text { Premonstratensi- } \\
\text { ans at Strahov }\end{array}$ & $1015000 \mathrm{CZK}$ & $0 \mathrm{CZK}$ & $0 \mathrm{CZK}$ \\
\hline $\begin{array}{l}\text { Městské muzeum } \\
\text { a galerie Hlinsko }\end{array}$ & $\begin{array}{l}\text { Hlinsko Munici- } \\
\text { pal Museum and } \\
\text { Gallery }\end{array}$ & $0 \mathrm{CZK}$ & $0 \mathrm{CZK}$ & $98000 \mathrm{CZK}$ \\
\hline
\end{tabular}

\footnotetext{
${ }^{19}$ Ministry of Culture of the Czech Republic. Acquisition Fund. Accessed June 19th, 2020, from https://www.mkcr. cz/akvizicni-fond-1697.html
} 
L. Horňáková - M. Prokůpek: Acquisition Fund: An unrecognised treasure...

\begin{tabular}{|c|c|c|c|c|}
\hline $\begin{array}{l}\text { Městské muzeum } \\
\text { a galerie Polička }\end{array}$ & $\begin{array}{l}\text { Poličkam Munici- } \\
\text { pal Museum and } \\
\text { Gallery }\end{array}$ & $0 \mathrm{CZK}$ & $128000 \mathrm{CZK}$ & $0 \mathrm{CZK}$ \\
\hline $\begin{array}{l}\text { Museum Kampa } \\
\text { - Nadace Jana a } \\
\text { Medy Mládkových }\end{array}$ & $\begin{array}{l}\text { Jan and Meda } \\
\text { Mládek Foun- } \\
\text { dation - Museum } \\
\text { Kampa }\end{array}$ & $4762960 \mathrm{CZK}$ & $5273000 \mathrm{CZK}$ & $1075000 \mathrm{CZK}$ \\
\hline $\begin{array}{l}\text { Muzeum Českého } \\
\text { ráje v Turnově }\end{array}$ & $\begin{array}{l}\text { Museum of The } \\
\text { Bohemian Para- } \\
\text { dise }\end{array}$ & $0 \mathrm{CZK}$ & $90780 \mathrm{CZK}$ & $100000 \mathrm{CZK}$ \\
\hline $\begin{array}{l}\text { Muzeum města } \\
\text { Brna }\end{array}$ & $\begin{array}{l}\text { Brno City Mu- } \\
\text { seum }\end{array}$ & $357000 \mathrm{CZK}$ & $0 \mathrm{CZK}$ & $704000 \mathrm{CZK}$ \\
\hline $\begin{array}{l}\text { Muzeum regio- } \\
\text { nu Valašsko ve } \\
\text { Vsetíně }\end{array}$ & $\begin{array}{l}\text { Museum of the } \\
\text { Wallachian Region }\end{array}$ & $0 \mathrm{CZK}$ & $0 \mathrm{CZK}$ & $168000 \mathrm{CZK}$ \\
\hline $\begin{array}{l}\text { Oblastní galerie } \\
\text { Liberec }\end{array}$ & $\begin{array}{l}\text { Regional Gallery } \\
\text { of Liberec }\end{array}$ & $250000 \mathrm{CZK}$ & $866976 \mathrm{CZK}$ & $0 \mathrm{CZK}$ \\
\hline $\begin{array}{l}\text { Regionální muze- } \\
\text { um v Kolíně }\end{array}$ & $\begin{array}{l}\text { Regional Museum } \\
\text { in Kolin }\end{array}$ & $0 \mathrm{CZK}$ & $259000 \mathrm{CZK}$ & $68000 \mathrm{CZK}$ \\
\hline $\begin{array}{l}\text { Severočeská } \\
\text { galerie výtvarného } \\
\text { umění v Litomě- } \\
\text { řicích }\end{array}$ & $\begin{array}{l}\text { The North Bo- } \\
\text { hemian Gallery } \\
\text { of Fine Arts in } \\
\text { Litoměrice }\end{array}$ & $252000 \mathrm{CZK}$ & $376000 \mathrm{CZK}$ & $309000 \mathrm{CZK}$ \\
\hline $\begin{array}{l}\text { Severočeské mu- } \\
\text { zeum v Liberci }\end{array}$ & $\begin{array}{l}\text { The North Bohe- } \\
\text { mian Museum in } \\
\text { Liberec }\end{array}$ & $288000 \mathrm{CZK}$ & $90000 \mathrm{CZK}$ & $600000 \mathrm{CZK}$ \\
\hline $\begin{array}{l}\text { Slovácké muze- } \\
\text { um v Uherském } \\
\text { Hradišti }\end{array}$ & $\begin{array}{l}\text { The Museum of } \\
\text { Moravian Slovakia }\end{array}$ & $0 \mathrm{CZK}$ & $0 \mathrm{CZK}$ & $770000 \mathrm{CZK}$ \\
\hline $\begin{array}{l}\text { Východočeská } \\
\text { galerie v Pardu- } \\
\text { bicích }\end{array}$ & $\begin{array}{l}\text { East Bohemian } \\
\text { Gallery in Pardu- } \\
\text { bice }\end{array}$ & $1460500 \mathrm{CZK}$ & $1774000 \mathrm{CZK}$ & $2075752 \mathrm{CZK}$ \\
\hline $\begin{array}{l}\text { Východočeské } \\
\text { muzeum v Pardu- } \\
\text { bicích }\end{array}$ & $\begin{array}{l}\text { East Bohemian } \\
\text { Museum in Pardu- } \\
\text { bice }\end{array}$ & $135000 \mathrm{CZK}$ & $0 \mathrm{CZK}$ & $0 \mathrm{CZK}$ \\
\hline $\begin{array}{l}\text { Západočeská } \\
\text { galerie v Plzni }\end{array}$ & \begin{tabular}{|l} 
Gallery of West \\
Bohemia in Pilsen \\
\end{tabular} & $126000 \mathrm{CZK}$ & $1589462 \mathrm{CZK}$ & $1295000 \mathrm{CZK}$ \\
\hline $\begin{array}{l}\text { Západočeské mu- } \\
\text { zeum v Plzni }\end{array}$ & $\begin{array}{l}\text { Museum of West } \\
\text { Bohemia in Pilsen } \\
\end{array}$ & $17500 \mathrm{CZK}$ & $0 \mathrm{CZK}$ & $0 \mathrm{CZK}$ \\
\hline Total subsidies & & $10088810 \mathrm{CZK}$ & $15453818 \mathrm{CZK}$ & $15715260 \mathrm{CZK}$ \\
\hline
\end{tabular}

The most successful institution is the private not-for-profit Jan and Meda Mládek Foundation - Museum Kampa, receiving 26.93\% of all the funding to acquire 22\% (64 artworks) of all artworks supported by the fund over three years.

The Acquisition Fund offers institutions the opportunity to increase their investment budgets for acquisitions by $70 \%$. The fund can finance a maximum of $70 \%$ of the total price of an artwork; this amount cannot exceed 1,000,000 EUR after recalculation at the exchange rate applicable on the date of submission of the application, and the total support from all public sources for the purchase of a particular artwork must not exceed $80 \%$ of the selling price of 
the artwork. Studying the yearly financial reports of ten interviewed art museums, it appears that different art museums are employing various strategies to receive funding. Four out of all interviewed art museum professionals approach this maximum range with the Acquisition Fund covering their acquisition investment budgets by $60 \%$ to $70 \%$. Two other art museums interviewed fund approximately $35 \%$ of their acquisition through the Acquisition Fund. The remaining three art museums that were interviewed had a rate in between $17.5 \%$ and $25.5 \%$. No straightforward approach is visible while looking at the nominal number of funded acquisitions and the total number of acquisitions for the particular institutions by year. The highest rate is $93.1 \%$, while the lowest is $1 \%$ of the number of acquired artworks being supported by the Acquisition Fund.

Notably, the Gallery of Modern Art in Hradec Králové took quite a risky path when its acquisition plan for 2019 merely counted on the Acquisition Fund's support. However, this precarious strategy paid off and has allowed them to expand their collection appreciably. The Gallery of Modern Art in Hradec Králové almost tripled their budget acquisition compared to the previous year. The support of the Acquisition Fund represents 67.2\% of the overall acquisition budget; the remaining part was financed by exceptional funding from the municipality investment fund. Thanks to this generous financial support, the art museum has acquired 29 new artworks. As stated in the current acquisition policy of the art museum, artworks purchased are of the nature of art installations and videos, completed by paintings of artists of the Czechoslovak post-revolutionary generation.

When looking at the price level of funding, the subsidies for single artworks cover a whole range of values going from 1,015,000 CZK (37,340 EUR) down to 9,000 CZK (331 EUR). A broad spectrum of price levels is also visible when evaluating the particular institutions; each of them asks for funding for high valued and less valued artists or more valuable and less valuable media within any given year. The differentiated portfolio reflects the need to co-finance acquisitions by at least 30\% of the artwork's price. However, the issue of this $30 \%$ co-financing rate directive is brought up by one respondent who worries that the participatory budget structure limits acquisitions of the highest quality artwork due to the inadequate acquisition budgets of art museums.

\section{Limitations and Pitfalls of the Application Process}

The Acquisition Fund provides direct subsidies to art museums to stimulate the acquisition of contemporary art. As a subsidy of the Ministry of Culture, specific eligibility requirements are imposed. These entail a formal presentation by applying institutions, a description and an explanation of entitlement for planned art acquisitions by applying institutions, as well as "proofs of the excellency" of planned acquisitions. While formal conditions are clearly understood, and a necessary paperwork activity for museums, the demonstration of an artwork's uniqueness for a particular art collection might be a restraint.

The application process for support from the Acquisition Fund requires the filling out of a basic form which includes three obligatory annexes (affidavits declaring the correct settlement of obligations to the state, eligibility to apply for state subsidies according to the minimum criteria, and the appropriate pursuance of EU Commission Regulation no. 651/2014 of June 17th, 2014). Moreover, applicants need to attach three documents certifying the legal existence of the applying institution. Beside all formalities, applicants then need to provide six descriptive documents for each individual artwork-to-be-acquired as evidence of its 
exceptionality (evidence of artwork being exhibited, coverage in catalogues or a professional press publication and expert testimony), and its suitability (acquisition strategy, acquisition commission protocol and curatorial report) for a particular art museum collection. As cultural authorities, art museums need to comprehensively explain the significance of the collection as a whole and each artwork. Collecting policies developed by curators and directors and curatorial reports to justify acquisition expenditures may fulfil the explicit statement's function, but may not validate the market value. ${ }^{20}$ To evaluate the acquisition as appropriate from both cultural and economic points of view, the ensemble of statements must be elaborated upon.

The conducted interviews revealed that museum directors consider the Acquisition Fund's application process to be administratively demanding and time-consuming. They, however, do not oppose the validation process. "Even though the administration is difficult, it is acceptable given the opportunity the fund brings to us." ${ }^{21}$ Nevertheless, among 29 applying institutions in three years, eight did not apply again after the first successful, but deterrent, application. Their main restraint is the extensive paperwork and the obligation to confirm an expert testimony, representing additional costs for art museums. "For the smaller-scale art institution focused on graphics, illustrations and works on paper, thus artworks of lower financial value, the unsure rentability of the pre-existing flat cost is the demotivating factor." 22 The other four directors interviewed mentioned the expert testimony as an issue they need to tolerate unwillingly. There are only a small number of respected experts in the field, which is problematic, compounding the above-described issue of additional costs. On the other hand, two directors claimed that they must have written expert testimonies within standard documentation for their acquisition commissions or their founders, being it municipality or regional government. The attitude towards the requirement of the expert testimony differs according to the subjective experience of interviewees.

In contrast, a consensual reproach among all interviewed institutions is the schedule of the call for support from the Acquisition Fund. The gap between the submission deadline, which is at the end of August, and the publishing of applications to be supported, which happens at the end of December, puts institutions and concerned artists/providers and even regional administrations on hold in a period of uncertainty. In the case of a successful application, this period is afterward followed by a critically short time left for the realisation of the purchase and billing of the subsidy strictly by the end of the fiscal (equals calendar) year.

[The gallery] offers/demands an artist to acquire his/her artwork. But firstly, [it] needs the purchase to be approved by [its] acquisition commission, which meets once a year, usually in September. As the acquisition commission protocol is a mandatory document within the call, the application cannot be submitted before the call in the following year. And still without certainty whether it will be financially supported. This unpredictability also complicates the co-financing of the supported acquisitions that again results in a long administration process within regional administrations agendas and a risk not to be approved in such a short time. The artist holds the artwork for more than a year with no security that [the gallery] will have money for his acquisition. ${ }^{23}$

\footnotetext{
${ }^{20}$ YOUNG, Linda. Significance, connoisseurship and facilitation: New techniques for assessing museum acquisitions. In: Museum management and curatorship, 1994, pp. 191-199.

${ }^{21}$ Interview with Miroslav Divina, the director of the Gallery of Modern Art Roudnice nad Labem. Roudnice nad Labem, August 2019.

${ }^{22}$ Interview with Hana Nováková, the director of The Art Gallery in Havlíčkuv Brod. Havlíčkův Brod, August 2019.

${ }^{23}$ Interview with Jan Randáček, the director of Regional Gallery of Liberec, Liberec September 2019.
} 
The criterion of the significance of the artwork within the art environment is required to be proclaimed by its exhibition history and its coverage within a professional publication. Eight out of ten interviewed art museum professionals consider acquisitions of particular artworks based on their exhibitions programme. "Once we take time and put a lot of energy to examine particular artworks in detail, to visit artist studios and make selections of the highquality pieces, we want those investments to be valued. The acquisition is the way to complete that effort." 24 Artwork intended to be purchased with the Acquisition Fund's support needs to have been previously exhibited and included in an exhibition catalogue or a professional artoriented publication.

Moreover, in regional art museums, $90 \%$ of purchases of artworks are made directly from artists or their inheritors. A purchase through commercial art galleries occurs in some cases; however, the low number of commercially represented artists does not create any pressure in that sense, although the professional approach of commercial art galleries encourages the involvement of represented artists into curatorial programming. Being aware of the potential for a publicly exhibited artist's work to increase in value, commercial art galleries offer discounts equal to the VAT rate $(20 \%)$ or even more exciting discount rates to make artworks more affordable for non-profit institutions. ${ }^{25,26,27}$ The commercial art galleries also play an essential role in popularising represented artists through exhibiting their artworks at international art fairs that can attract tremendous worldwide media coverage and the attention of collectors, curators and art lovers.

The requirement for an artwork intended for acquisition to have been published in an exhibition catalogue or a periodical art-oriented publication, online or offline, might be another pitfall of the application process. The Czech Republic still lacks a sufficient level of such an art-oriented press. Therefore, this might limit the evidence that the artwork has been published in the professional media, a collective publication or exhibition catalogue, or professionally evaluated on an online platform. However, this limitation is not considered as the main issue among the majority of interviewed art museums. Only two participants in the research pointed out this issue, spontaneously, as problematic. Art museums, having their acquisition strategy focused intrinsically, rely mainly on their publishing activities, referring to past exhibitions.

The most important document required is the descriptive explanation of the acquisition. The artwork to be acquired needs to meet the strictest requirements of artistic quality and represent a significant developmental trend in contemporary art. Notwithstanding, no other guidelines specify criteria for measurement of the uniqueness of the art, nor the part played in developing a contemporary trend. It is up to curators to elaborate on why the artwork represents a significant enrichment and appreciation of the cultural heritage. As for regional art museums, their acquisition strategy is focused on the artworks of both established and emerging contemporary artists. Their vision is to fill a gap in the acquisitions caused by a communistic political establishment. The artworks of renowned artists rarely appear on the market, and if so, art museums' budgets cannot compete with private sector collectors.

Consequently, the acquisitions of all interviewed art museums (except for the regional gallery with a stable, historically given orientation towards Russian art) focus mainly on the generation of artists which has taken the scene from the 80 s onwards. $50 \%$ of all purchases

\footnotetext{
${ }^{24}$ Interview with Marcel Fišer, the director of The Art Gallery in Cheb, Cheb September 2019.

${ }^{25}$ Interview with Filip Polanský, the director of the Polansky Gallery, September 2018.

${ }^{26}$ Interview with Mikuláš Nevan, the director of the Nevan Contempo, September 2018.

${ }^{27}$ Interview with Edmund Čucka, the sales executive at DSC Gallery, August 2018.
} 
supported by the Acquisition Fund were artworks from the 1970s to 2000s, and the second half was of post-millennium artworks. The funding of " 80 s generation artworks" represents $55 \%$ of the overall sum. That confirms the strategy to acquire "missing high-quality artworks" which are, yet, affordable.

The regional art museums have a good reputation among the Czech art scene. ${ }^{28}$ "Private collectors are open to lending artworks from their collections for [regional art museum's] exhibitions, and commercial gallerists and dealers offer discounts to them. Artists recognise the advantages of being included in [regional art museum's] collections." ${ }^{29}$ Except for one interviewed art museum, all agreed that being included in regional art museum collections positively impacts artists' careers. Local art museums' collections have significant visibility due to permanent or temporary exhibitions in these museums and loans among art museums. Referring to yearly reports of the interviewed institutions, on average, 1,300 artworks are yearly lent from regional art museums' collections. Also, seven out of ten interviewed museum professionals make efforts to build collaborations with international institutions to present Czech art abroad. The art museums see the opportunity to support artists through an acquisition policy. According to Czech legislation, art museums cannot pay any artistic fee for time and energy spent preparing, installing and promoting exhibitions. Acquisitions, therefore, serve as a compensating instrument - not to forget that art museums' deposits are ideal places to preserve the work of artists. These benefits augment the negotiating power of art museums when it comes to prices.

Regarding the territorial structure, art museums, in general, feature the nationwide context. However, the emphasis on local artists is marginalised, highlighted by just four regional art museums incorporating local names in their programming. They also understand their role as institutions of memory, responsible for honouring local artists. Three of ten interviewed art museums have developed a specific approach towards contemporary art to alternate their programming. Further, various strategies are being adopted by museums to make their programming more distinctive: collaboration with art awards for young emerging artists; cycles of exhibitions dedicated to artists more youthful than forty years old; the use of new media; or the embracing of a Central European focus. The art museums need to submit persuasive curatorial reports to convince the Council of the Acquisition Fund that their acquisition selection is significant either in the territorial context or the collection-wise context. Together with protocols of the individual acquisition commissions of the art museums, these documents act as objectifying factors regarding the administration process.

However, the required documentation's qualitative character defines the Acquisition Fund subsidy more as a grant with unpredictable selection outcomes. On the other hand, repeating successful submissions certifies an institution's quality in the eyes of the particular regional administration by which it was founded. A positive image endorsed by the Council of Acquisition Fund, formed by professional experts, confirms or encourages a regional administration to invest in the institution.

\footnotetext{
${ }^{28}$ Artyčok TV: Kam kráčí Národní galerie?, accessed October 11th, 2020, https://artycok.tv/43350/kam-kraci-narodni-galerie.

${ }^{29}$ Interview with Petra Př́kazká, the chief curator of the Gallery of Modern Art in Hradec Kralove, Hradec Králové September 2019.
} 


\section{Conclusion}

The Acquisition Fund, as the support and the stimulus for contemporary art acquisitions launched by the Ministry of Culture of the Czech Republic as stated in the Cultural Policy for 2015-2020, is the critical aspect helping Czech art museums to enrich their collections with valuable artworks of the older, middle and younger generations of contemporary artists. The fund provides subsidies for a potentially significant number of institutions as indirect finance for artists or their gallerists.

Due to the fund's existence, the overall budget for acquisitions of ten interviewed art museums increased by $23.5 \%$. With a detailedly defined acquisition conception and resourcefully supported by their regional administrations, the most successful art museums have increased their budgets by up to $60 \%$. Satisfaction as well as the positive attitude of interviewed institutions affirms the efficiency of the fund. Moreover, the Ministry of Culture has declared that the fund offers more significant financial potential.

Applying institutions need to consider their acquisition budgets when preparing applications; they need to think of the minimal 30\% co-financing directive, which forms barriers to unlimited requests. The exhaustive documentation that has to be submitted for each artwork to be acquired individually also sets impediments for rather small art museums' teams - this being one reason why the number of applying institutions is surprisingly low. Elaborating closely on the application process requirements, they are set to enrich art museums' collections with previously endorsed high-quality artworks. None of the requirements imposes overly high demands. This is confirmed by twenty-nine successful applicants who represent the wide scale of eligible, yet not applying, institutions. The double revision of planned acquisitions by the internal commissions and by the Acquisition Fund's Council objectifies the selection and, thus, the art collections. The two-step control more accurately validates public money spending on cultural patrimony.

That said, the low number of applicants could be caused by inadequately set rules for acquisitions within art institutions themselves. These rules do not meet the more objective standards of the Acquisition Fund. The acquisition policies of art museums are not clearly defined, implicating the non-continual building of art collections. Once a generational gap of the artists represented within a collection occurs, it is difficult to fill it later. This is because of high costs and low supply. Institutions should rethink their acquisition strategy protocols for contemporary art following the Acquisition Fund's standards. The fund significantly helps institutions to avoid the risk of such a collectibles gap, and provides the essential financial support to complete a collection with the works of missing artists.

\section{Acknowledgment}

The research was realised with financial support from the IGA/A grant competition of the Prague University of Economics and Business OP VVV IGA/A, CZ.02.2.69/0.0/0.0/19_07 3/0016936 number IG302029. 
L. Horňáková - M. Prokůpek: Acquisition Fund: An unrecognised treasure...

\section{References}

\section{Literature}

ALTSHULER, Bruce (ed.) (2007). Collecting the new: museums and contemporary art. Princeton University Press. ISBN 9780691133737.

CHARMAZ, Kathy (2014). Constructing grounded theory. London: SAGE Publications. ISBN 9781446297223.

FALK, John H. and SHEPPARD, Beverly K. (2006). Thriving in the knowledge age: New business models for museums and other cultural institutions. Oxford: Altamira Press. ISBN 978-0759107588.

FIALOVÁ, Dagmar (2003). Profesni a etické standardy a výkonnostni ukazatele murejni práce. Praha: Asociace muzeí a galerií. ISBN 80-86611-02-7.

GENOWAYS, Hugh H.; IRELAND, Lynne M (2003). Museum administration: An introduction. Altamira Press. ISBN 978-0759102941.

GLASER, Barney G. and STRAUSS, Anselm L (1967). The discovery of grounded theory: Strategies for qualitative research. London: AldineTransaction. ISBN 0-202-30260-1.

NAIRNE, Sandy (1999). Exhibitions of contemporary art. In: Barker, E (ed). Contemporary Cultures of Display, 105-126. ISBN 978-0300077834.

NÁRODNÍ INFORMAČNÍ A PORADENSKÉ STŘEDISKO PRO KULTURU (2019). Základni statistické údaje o kulture v Ceské republice 2018. Praha: NIPOS. ISBN 978-80-7068341-5.

PROKŮPEK, Marek (2020). Ekonomika a měreni výkonnosti muzeí. Praha: Wolters Kluwer ČR. ISBN 978-80-7598-686-3.

RYAN, Gwynne (2016). Considerations in the acquisition of contemporary art: Refabrication as a preservation strategy. In: Studies in Conservation, pp. 198-202. ISSN: 0039-3630.

STRÁNSKÁ, Edita., STRÁNSKÝ, Zdeněk (2008). Ozvláštnění skutečnosti: sběratelství a sbírkotvorná činnost. In: PACHMANOVÁ, Martina (ed). Mít a být, sbèratelství jako kumulace, recyklace a obsese. Praha: Vysoká škola uměleckoprůmyslová, pp. 43-44. ISBN 978-80-8686325-2.

VELTHUIS, Olav (2007). Talking prices: Symbolic meanings of prices on the market for contemporary art. Woodstock: Princeton University Press. ISBN 978-0691134031.

YOUNG, Linda (1994). Significance, connoisseurship and facilitation: New techniques for assessing museum acquisitions. In: Museum management and curatorship, pp. 191-199. ISSN: 0964-7775.

Czech Laws

Act No. 129/2000 Coll. On regions. In: Collection of Laws. 15.05.2000.

Act No. 250/2000 Coll. on Municipal Budgetary Rules. In: Collection of Laws. 09.08.2000.

Act No. 122/2000 Coll. on protecting collections of a museum character and applying specific laws. In: Collection of Laws. 12.05.2000.

\section{Online sources}

Artyčok TV: Kam kráčí Národní galerie?, accessed October 11th, 2020, https://artycok. tv/43350/kam-kraci-narodni-galerie

Centrální evidence sbírek muzejní povahy, accessed June 19th, 2020, http://www.cesonline.cz/ $\operatorname{arl}-$ ces/cs/index/ 
Ministry of Culture of the Czech Republic. Acquisition Fund, accessed June 19th, 2020, https://www.mkcr.cz/akvizicni-fond-1697.html

Interviews:

Interview with Edmund Čučka, the sales executive at DSC Gallery. Prague, August 2018.

Interview with Miroslav Divina, the director of the Gallery of Modern Art Roudnice nad Labem. Roudnice nad Labem, August 2019.

Interview with Marcel Fišer, the director of The Art Gallery in Cheb. Cheb, September 2019.

Interview with Hana Nováková, the director of The Art Gallery in Havlíčkuv Brod. Havlíčkův Brod, August 2019.

Interview with Mikuláš Nevan, the director of the Nevan Contempo. Prague, September 2018. Interview with Filip Polanský, the director of the Polansky Gallery. Prague, September 2018.

Interview with Petra Prríkazká, the chief curator of the Gallery of Modern Art in Hradec Kralove. Hradec Králové, September 2019.

Interview with Jan Randáček, the director of Regional Gallery of Liberec. Liberec, September 2019.

Interview with Eva Teuerová, representative of the Acquisition Fund of the Ministry of Culture of the Czech Republic. Prague, April 2020. 